\title{
VAS BERNADETT
}

vasdetti87@gmail.com

hallgató (SZTE JGYPK Juhász Gyula Pedagógusképző Kar,

Közösségi és civil tanulmányok szak)

\section{Színlelt izmusok. Könyvismertető.}

Pretended isms. Review.

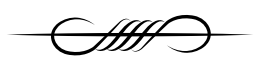

LAKi LÁszLó (2021). A „színlelt” szocializmusból, a „színlelt” kapitalizmusba. Szeged, Belvedere Meridionale

DOI 10.14232/belv.2021.4.8

https://doi.org/10.14232/belv.2021.4.8

Cikkre való hivatkozás / How to cite this article:

Vas Bernadett (2021): Színlelt izmusok. Könyvismertető. Belvedere Meridionale 33. évf. 4. sz. 115-118. pp

ISSN $1419-0222$ (print)

ISSN 2064-5929 (online, pdf)

(Creative Commons) Nevezd meg! - Így add tovább! 4.0 (CC BY-SA 4.0)

(Creative Commons) Attribution-ShareAlike 4.0 International (CC BY-SA 4.0)

www.belvedere-meridionale.hu

Laki László kutatásain keresztül a könyv egy magára hagyott társadalmat mutat be, melyet mélyebben megviselt a rendszerváltás, mint sok-sok korábbi történelmi év. Egy olyan rendszerváltás, melyre sem a vezetők, sem a magyar népesség nem volt felkészülve. Laki László más szemszögből közelít. Nem csak a rendszerváltás okozta modernizáció szemszögéből, hanem a mindennapi élet vonalán. Hogy tudja feldolgozni a változásokat Magyarország lakossága, akik már eddig is nagy nehézségekkel küzdöttek a mindennapi megélhetésért? Akik elméletben kapnak egy új ideológiát, miközben elveszítenek oly sok mindent. Megélik a Magyarországon történelmi háttérrel rendelkező mezőgazdaság megváltozását, összeomlását. Az iparosodás fejlődését, mely kiutat jelenthetett volna bizonyos régiókban, de pár év alatt ez is szintén csődöt 
mondott. Ezáltal kifordult a sarkából a világ a társadalom egy rétegének. Annak a rétegnek, akik a társadalom közepén, illetve legalján voltak. Vagy rövid időn belül a változások következtében lentre jutottak. Azoknak, akiknek a legnagyobb szükségük lett volna a segítségre. Kiútkeresés, vagy éppen úszni az árral. Kutatások, mely emberéleteken keresztül mutatja be a teljes kétségbeesést, a próbálkozásokat, és egy kis magyar valóságot.

Laki László azon kevesek között volt, akinek lehetősége volt Gazsó Ferenccel együttdolgozni. 1970-től empirikus kutatásokat végzett. Megtervezett kutatásait a rendszerváltás megváltoztatta. Fő munkái az ifjúságról, az oktatásról, valamint a magyar társadalom zárványtársadalmairól szóltak. A magyar társadalmat nemcsak a határokon belüli lakosokra leszükítve, hanem a határon túl élő, a trianoni békeszerződés által elszakított népességre és területekre is kibővítette. A könyv bemutatja Laki László szociológiai kutatásainak módszertani sokszínüségét is. Ahogy az elöszóban szerepel:

„A munkanélküliség hatásait, a kilábalás útjait firtató, a külföldi munkavállalás, vagy a háztájizás körülményeit stb. feltérképező interjúk, a közép-Tiszavidéki kistérségben és a Csíki medencében végzett empirikus felvételek, a szorult helyzetű család havi étkezési naplója, vagy a különböző statisztikai források használata ugyanakkor világosan jellemzik Laki László következetes kutatói attitűdjét." 1

És ez a rövid idézet tökéletesen bemutatja a könyvben szereplö kutatásokat, és magát a kutatót is.

A hetvenes és nyolcvanas években átalakult hazánkban az „első” és a „második” gazdaság. Azonban ez az átalakulás nem hozta magával azt a fejlődést, polgárosodást, mely által az ország felvehette volna a versenyt a gazdaságilag fejlett világgal. Az „első” és a „második” gazdaság egymással szoros viszonyban léteztek. A „második” gazdaság önmagában nem volt alkalmas a fejlődésre, az „első” gazdaságból származó alacsony jövedelmek kiegészítéseként beszélhetünk csak róla. Ez a folyamat a rendszerváltás után is befolyásolta az ország gazdasági helyzetét, valamint az egyének élethelyzetét.

Laki László kutatásaiban Magyarországon belül földrajzilag eltérő problémákkal, a társadalmi berendezkedés általi gondokkal, az oktatás problematikájával, az individumok mindennapi fájdalmaival és életével ismerkedhetünk meg. Tanulmányaiban a kvalitatív és a kvantitatív kutatási módszereket egyaránt használta.

Az elsődleges problémát az egész társadalomra kiterjedő nagyszámú munkanélküliségben látja, mellyel egyik érintett sem tudott mit kezdeni. Sem azok, aki elveszítették munkájukat, sem azok a vezetők, akik nem voltak erre a helyzetre felkészülve, és nem találták a megoldást. Habár kialakult egy segélyezései rendszer az országban, azonban ez olyan volt, mint egy nyílt csonttörésre a sebtapasz. Ez egy új társadalmi tömegjelenség volt. Laki László 1992-ben készült Munkanélküliség és bünözés munkájából származó idézet jól mutatja a társadalom vertikális ellentéteit. „A munkanélkülit a vállalkozó, a segélyeket elosztó állam és önkormányzat marasztalja el (pl. ingyenélő, semmittevő); a vállalkozót az állam, az önkormányzat, a munkanélküli (pl. adócsaló, konjunktúralovag); az államot pedig a vállalkozó, az önkormányzat, a munkanélküli (pl. hitelkamatok megemelése, az állampolgárok túladóztatása, a vállalatok felszámolása miatti

LAKi LÁszló (2021). A „színlelt” szocializmusból, a „színlelt” kapitalizmusba. Szeged, Belvedere Meridionale. 13,14 . 
elbocsájtások)." ${ }^{2}$ Rétegeken belül még jobban fellelhető volt a megértés, azonban olyan ellentétek születtek a társadalomban, melyek még a mai napig meghatározók. Ezen problémáknak maga a munkanélküliség csak egy darabja. A kutató innét eredezteti az elvándorlásokat nyugatra egy jobb élet reményében. Egy olyan deviáns társadalom kialakulását, ahol az alkoholizmus, a drogok, a bünözés egy alternatív kiút az emberek számára a mindennapok megélhetéséhez, és a túléléshez. A fiatalok életében történt változások, a szülőktől való elszakadás kitolódása, vagy a családalapítás kérdése, melyek még mind a mai napig fellelhető problémák.

Megfigyelhető volt, hogy egyre nagyobb tömegek helyezkedtek el a szolgáltató szektorban mindenhol. De az országban jól kimutatható a társadalomnál egy földrajzi elhelyezkedésen alapuló rétegződés. Itt nem csak a főváros, nagyváros, kisváros, falu közötti különbségeket kutatja (habár itt is nagy különbségek észlelhetők), hanem régiónként. A lehetőségek szemszögéből. Ahol korábban nagy volt a mezőgazdaságban a foglalkoztatás, ott sokkal nagyobb százalékban alakult ki probléma a rendszerváltás után, amikor a privatizációk hatására ez átalakult. Ott, ahol az iparosítás megindult, majd csődbement. Ahol, ha nem volt alaptőke - és a legtöbb vizsgált embernek nem volt - és nem tudtak céget alapítani, akkor elindult az egyén a lejtőn. Válaszút elé került. Sodródik, és él a segélyezési rendszer lehetőségével, bevállal bármilyen munkát, ahol lehet, kevesebbet fog keresni, mintha segélyen élne. Vagy a családját „hátrahagyva” külföldön, vagy az ország más, fejlettebb régióiban vállal munkát, ami újabb kihívások elé állítja. Magyarországon az egykeresetü családi modell volt sok időn keresztül jellemző. Így a nők helyzetében a történelmi visszatekintést is figyelembe véve a rendszerváltás még nagyobb problémákat okozott. A példaként hozott kunhegyesi kutatás ezt jól mutatja. A térségben a nők feladatai a házi munkán, gyermeknevelésen, vagy a háztájizáson már túlmutattak, hiszen a család fenntartásához nélkülözhetetlen volt, hogy ők is állást vállaljanak. Viszont alacsonyabb iskolai végzettségük miatt milyen munkát is tudnak vállalni? Arról már nem is beszélve, hogy ezt milyen bérért teszik? Habár megvolt egy bizonyos szintü társadalmi háló, azonban a legtöbbjüknek nem tudtak munkát biztosítani a képességeik, körülmények miatt. Hiába lett a probléma közügy, a segélyek elosztásába belebukott a rendszer. És a mai napig felmerülő kérdés: segély vagy munka? Nem beszélve a sokakat érintő devianciáról, mely a családokat érintette. A megélhetésért loptak (pl.: ételt, vagy fát, hogy füteni tudjanak télen), a nehézségek miatt megugrott a családon belüli erőszak, az alkoholizmus és egyéb függőségek. A válások száma is nagyban megnövekedett a kialakult körülmények miatt.

A kunhegyesi példa jól ábrázolja a regionális különbségeket is. Nem csak városok-falvak, mezőgazdasági-ipari régiók közötti különbségek nagyok az országban, hanem például a tömegközlekedésből kimaradt régiók elmaradottsága is megfigyelhető. Azon városok („kapuvárosok"), régiók, melyekben a külföldi befektetők nagyobb potenciált láttak, ugrásszerüen fejlődtek, így még nagyobb lett az országon belüli társadalmi különbség. A hazai tőkehiány miatt bekerült külföldi befektetések azonban nem a hazai társadalom fejlödését adták, hiszen a haszon nem itt realizálódott.

És mindezek milyen példát mutattak és mutatnak mind a mai napig a fiataloknak? Milyen lehetőségeik voltak és vannak a felnövekvő nemzedékeknek? A munkaerőpiacra való bekerülésük kilátástalanná vált, hiszen olyan elvárásokat támasztottak velük szembe, melyeket nem lehetett teljesíteni (pl.: pályakezdőként gyakorlati idő). A szülőkre olyan teher került, amivel

\footnotetext{
LAKi László (2021). A „színlelt” szocializmusból, a „színlelt” kapitalizmusba. Szeged, Belvedere Meridionale. 33.
} 
nem tudtak a legtöbb esetben megküzdeni. A saját életük, a mindennapi túlélés mellett szembesülniük kellett azzal, hogy a korábbi évekhez, évtizedekhez képest a gyermekeik sokkal később repülnek ki a családi fészekből. Nehezebben tudnak elhelyezkedni, és így a családok élete még nehezebbé vált, hiszen hosszabb ideig kellett támogatniuk a szülőknek a gyermekeiket. Ami az alapból is szegény körülmények közt élök életét még jobban megnehezítette. Sok család nem tudta biztosítani gyermekének a megfelelő oktatást sem. A fiatalok életében a kételyek mellett kitolódott a családalapítás, hiszen ilyen körülmények, a bizonytalanság, lakhatási nehézségek között realizálódott bennük, hogy erre nem lehet építkezni. A munka melletti folyamatos tanulás, valamint attól a félelemtől, hogy elveszítik a már megszerzett állásukat, a fiatalok prioritási rendjében a családalapítás hátrébb sorolódott, saját életük, értékeik kialakításával voltak elfoglalva. Elötérbe kerültek a korábban elítélt élettársi viszonyok. Depresszió, deviancia alakult ki, mely még nagyobb nyomorba sodorta az érintetteket. Hasonlóan, mint az egész rendszerváltásra, a családok, az iskolai rendszer, az önkormányzatok, és egészében az állam nem volt erre a helyzetre felkészülve. És ez a helyzet még a felsőfokú tanulmányokat elvégzőket is érintette. A „modernizációs kényszer”, és a vele szembenálló nehézségek, körülmények a korábbiaknál sokkal jobban megnehezítik a fiatalok helyzetét.

A könyvben szereplő interjúk adják az igazi ízét a tanulmányoknak. Ettől lesz öszinte. Néha kicsit talán nyersnek tủnnek, de ilyen a való élet. Igaz emberek, igaz életek, gondolatok, érzések. Problémák, élethelyzetek, kétségbeesések, kiútkeresések. És a rendszerváltás utáni, jelenlegi helyzetben is fellelhető problémák. A változás okozta nehézségek, melyek a mindennapi emberek, mindennapi éltét befolyásolják. Döntések, melyek életeket változtatnak meg. Néha jó, néha rossz irányba, és aminek az eredménye csak évekkel később realizálódik igazán. Megváltozott az élet Magyarországon a rendszerváltás után, ez mindenki számára világos. És mindenki akarta is ezt a változást, habár nem biztos, hogy ebben a formában. A kérdés már csak az, hogy az adott helyzetből mi lesz. Lehet-e megoldást találni a társadalmi problémákra, hogy ez csak egy átmeneti helyzet, mely egy tanulási folyamat mindenki számára? A társadalmi változások, legyenek azok külső, vagy belső indíttatásúak, jó és rossz döntések sorából áll. A könyvben szereplő tanulmányok, felvetések, életek bemutatása talán azok számára, akik elolvassák lehetőséget adnak arra, hogy mindezeket átgondolják, és inspirálja őket a megoldások keresésére. 